\section{An EcoRI polymorphism for the glutaminyl-tRNA synthetase (QARS) gene on chromosome 1q}

\author{
A.K.Sander ${ }^{\star}$, S.Liechti-Gallati ${ }^{1}$, N.Kunze ${ }^{2}$, H.Moser ${ }^{1}$, \\ M.Zingg and J.Raveh \\ Division of Craniomaxillofacial Surgery, Department of \\ Otolaryngology, University of Berne, ${ }^{1}$ Medical Genetics \\ Unit and Molecular Genetics Laboratory, Department of \\ Pediatrics, Inselspital, University of Berne, CH 3010 \\ Berne, Switzerland and 2Faculty of Biology, Unıversity of \\ Konstanz, PO box 5560, 7750 Konstanz, Germany
}

Source/Description: A 480 bp EcoRI-HindIII restriction fragment (Pz480), isolated from the GlnRS-specific Pz-cDNA (coding for the central core region of the GlnRS-enzyme) (1) cloned into the EcoRI-site of pUC9.

Polymorphism: EcoRI detects polymorphic fragments of $6.5 \mathrm{~kb}$ (A1) and $3.5 \mathrm{~kb}$ (A2).

Frequency: The allele frequencies were determined by typing 47 unrelated European Caucasians.

$\begin{array}{llll}\text { Enzyme } & \text { Allele } & \text { Fragment Size } & \text { Frequency } \\ \text { EcoRI } & \text { A1 } & 6.5 \mathrm{~kb} & 0.25 \\ & \mathrm{~A} 2 & 3.5 \mathrm{~kb} & 0.75\end{array}$

Chromosomal Localization: QARS was mapped to $1 \mathrm{q} 32-42$ by Southern blot analysis of somatic cell hybrid lines and in situ chromosomal hybridization (2).

Mendelian Inheritance: Co-dominant segregation was observed in one large three-generation kindred, another three threegeneration families and in three two-generation families with a total of 46 children.

Probe Availability: Available from N.Kunze.

References: 1) Thömmes,P., Fett,R., Schray,B., Kunze,N. and Knippers,R. (1988) Nucleic Acids Res. 16, 5391-5406. 2) Kunze,N., Bittler,E., Fett,R., Schray,B., Hameister,H., Wiedorn,K.H. and Knippers,R. (1990) Hum. Genet. 85, $527-530$.

* To whom correspondence should be addressed at Nordwestdeutsche Kieferklinik, Clinic of Oro-Maxillo-Facial Surgery, Martinistrasse 52, 2000 Hamburg, Germany

\section{RFLP detected by a genomic probe from the human $X$-linked proteolipid protein gene, PLP}

Wendy H.Raskind', John Wolff', Lynn D.Hudson² and Thomas D.Bird ${ }^{1,3}$

'Department of Medicine, University of Washington School of Medicine, Seattle, WA 98195, 2Laboratory of Viral and Molecular Pathogenesis, National Institute of Neurological Disorders and Stroke, National Institutes of Health, Bethesda, MD and 'Division of Neurology, Veteran's Affairs Hospital, Seattle, WA, USA

Source/Description: Probe pJB010 is a $4.2 \mathrm{~kb}$ SalI-BamHI genomic fragment cloned in pTZ19R, that contains the promotor and upstream regulatory elements of the PLP gene and extends into the first exon $(1,2)$.

Polymorphism: A restriction fragment polymorphism with alleles $2.7 \mathrm{~kb}(\mathrm{~A} 1)$ and $2.6 \mathrm{~kb}(\mathrm{~A} 2)$ is identified by MspI (5'-CCGG-3') digestion.

Frequency: $\mathrm{C} 1: 0.65, \mathrm{C} 2: 0.35$

Observed Heterozygosity: 0.46; studied in 114 unrelated X chromosomes in Caucasians.

Chromosomal Localisation: The human PLP gene maps to Xq21.3-q22 (3).

Mendelian Inheritance: X-linked recessive inheritance of PLP has been demonstrated (3). Defects in this gene are responsible for Pelizaeus - Merzbacher disease (PMD, 1-4). The alteration in PLP is unique for each of the PMD families in which the molecular defect has been described. Linkage to PLP has been shown in families in which no intra-exonic mutations were found $(4,5)$. Therefore, molecular screening of new cases will entail evaluation of the entire PLP locus; the method of carrier detection and prenatal diagnosis would be dependent on the specific mutation found. The RFLP system described herein may be helpful in the evaluation of families exhibiting neurologic disorders suggestive of PMD.

Probe Availability: Dr. Lynn Hudson.

Other Comments: It is not necessary to cut the genomic insert from the plasmid prior to use, nor is it necessary to prehybridize blots with total human DNA to obtain clean autoradiographs. The stringency wash is at $65^{\circ} \mathrm{C}$ for 30 minutes in $0.1 \times \mathrm{SSC}$ and $0.1 \%$ SDS. For adequate separation of bands on $0.8 \%$ agarose, a constant band at $1.2-1.3 \mathrm{~kb}$ is usually run off the gel.

Acknowledgement: Supported by grant CA 16448 from the NIH.

References: 1) Hudson,L.D. et al. (1989) Proc. Natl. Acad. Sci. USA 86, 8128-8131. 2) Raskind,W.H. et al. (1991) Am. J. Hum. Genet. 49, 1355-1360. 3) Willard,H.F. et al. (1987) Cytogenet. Cell Genet. 46, 716. 4) Trofatter,J.A. et al. (1989) Proc. Natl. Acad. Sci. USA 86, 9427 -9430. 5) Pham-Dinh,D. et al. (1991) Proc. Natl. Acad. Sci. USA 88, 7562-7566. 